Article

\title{
Sustainable Development of China's Industrial Economy: An Empirical Study of the Period 2001-2011
}

\author{
Huijun Li ${ }^{1,2, *}$, Jianhua Zhang ${ }^{1}$, Edward Osei ${ }^{3}$ and Mark Yu ${ }^{3}$ \\ 1 School of Economics, Huazhong University of Science and Technology, Wuhan 430074, China; \\ jhzhanghust@163.com \\ 2 Division of Arts, Humanities, \& Social Sciences, Victoria College, Victoria, TX 77901, USA \\ 3 Department of Agricultural and Consumer Sciences, Tarleton State University, Stephenville, TX 76401, USA; \\ osei@tarleton.edu (E.O.); yu@tarleton.edu (M.Y.) \\ * Correspondence: huijun.li@victoriacollege.edu; Tel.: +1-254-459-1361
}

Received: 26 December 2017; Accepted: 8 March 2018; Published: 10 March 2018

\begin{abstract}
In this paper, we investigate the implications of continued industrial economic growth on environmental pollution in China in order to inform strategic policies to achieve sustainable development of the industrial sector. We calculate green total factor productivity (TFP) for each industrial sector by estimating the Global Malmquist-Luenberger (GML) index using a Slacks-based Measure Directional Distance Function (SBM-DDF). We find that the green TFP increased at an average annual rate of approximately $6 \%$ over the 11 -year period. A slightly greater portion of this growth is attributable to technological progress (57\%) rather than technical efficiency (43\%). To investigate the relationship between industrial economic growth and pollutant levels, we first adopt a hierarchical clustering procedure to group all industrial sectors into green-intensive, intermediate and extensive clusters based on the contribution of green TFP to industrial economic growth within respective industries. Based on an econometric estimation of the relationship between pollutant levels and industrial GDP per capita, we find clear evidence in favor of the Environmental Kuznets Curve (EKC) theory only with wastewater as the primary pollutant of interest and only with industrial sectors that are already relatively pollution intensive. We find no evidence in support of the EKC theory when sulfur dioxide or solid waste is the pollutant of major concern. In general, blindly accelerating industrial economic growth will likely worsen environmental quality, unless reasonable environmental policy interventions are implemented.
\end{abstract}

Keywords: environmental kuznets curve; industrial sectors; environmental pollution; green total factor productivity; industrial economic growth; sustainable development; slacks-based; directional distance function

\section{Introduction}

The rapid development of China's economy, largely attributable to its industrial sector, has also resulted in increased resource depletion and environmental pollution. Over the past four decades, China has transitioned from a state of energy self-sufficiency to a high degree of energy dependence, with energy consumption in the industrial sector accounting for over $80 \%$ of the national total. Over the same period, severe environmental pollution has accompanied the dramatic rise in energy use. Based on the 2016 Report of Trends in Global $\mathrm{CO}_{2}$ emissions, China's emissions increased by $10 \%$ from 2002-2011, generating per capita $\mathrm{CO}_{2}$ emissions of 7.7 tons by 2015 [1]. While it is not among the nations with the highest per capita $\mathrm{CO}_{2}$ emissions, China, due in part to its large population, is currently the world's highest carbon emitter, with total $\mathrm{CO}_{2}$ emissions of 10,433 Mt in 2016. China's total $\mathrm{CO}_{2}$ emissions represent about $29 \%$ of the global total [2], about $84 \%$ of which is attributable to 
its industrial sector [3]. Clearly, the current growth pattern of China's economy may not be sustainable if prevailing environmental pollution rates are not reduced.

Many studies have used green total factor productivity (TFP) to gauge the degree of sustainability of industrial economic growth. The traditional TFP calculated by using only capital and labor as major inputs, neglects pollutant byproducts and energy consumption, thus distorting the implications of environmental impacts on sustainable development. By accounting for energy consumption and including environmental pollution as undesirable outputs, many studies have estimated green TFP growth rates in the industrial sector of China and other countries (see Table 1). The studies represented in Table 1 are illustrative of the many works that acknowledged the role of energy inputs and pollutant output in better reflecting sustainability of industrial growth. The vast majority of these studies employed a directional distance function (DDF) to estimate green TFP [4-6]. Furthermore, most of these studies used a version of the Malmquist-Luenberger (ML) productivity index in their estimations [4-8]. Virtually all studies concluded that TFP is overestimated when undesirable outputs are ignored. This paper employs similar but more advanced methods to estimate green TFP for China's industrial sector, as described below. As the predominant contributor to China's GDP and environmental pollution, attention has turned to the industrial sector to improve the contribution of green TFP-a measure of sustainability-to total economic output. This paper contributes to our understanding of the long-term sustainability of China's industrial economy.

Table 1. Summary of scope, methodology and conclusions of related studies on green TFP.

\begin{tabular}{|c|c|c|c|c|c|}
\hline Study & Scope & $\begin{array}{l}\text { Major Issues } \\
\text { Addressed }\end{array}$ & Inputs/Outputs & Methodology & Major Conclusions \\
\hline Zhang et al. [4] & $\begin{array}{l}\text { Provincial } \\
\text { level }\end{array}$ & $\begin{array}{l}\text { Compare traditional TFP } \\
\text { and TFP including } \\
\text { undesirable outputs in } \\
\text { China's } 30 \text { provinces }\end{array}$ & & $\begin{array}{l}\text { Directional Distance } \\
\text { Function and } \\
\text { Malmquist-Luenberger } \\
\text { productivity index }\end{array}$ & $\begin{array}{l}\text { TFP overestimated if } \\
\text { undesirable outputs } \\
\text { ignored. Environmental } \\
\text { regulation in China far } \\
\text { below levels in the best } \\
\text { performing regions; } \\
\text { greater enforcement } \\
\text { helps improve } \\
\text { productivity growth. }\end{array}$ \\
\hline $\mathrm{Li}$ and $\operatorname{Lin}[5]$ & Industry & $\begin{array}{l}\text { Measure green } \\
\text { productivity growth of } \\
36 \text { industrial sectors in } \\
\text { China over 1998-2011 }\end{array}$ & $\begin{array}{l}\text { Energy consumption as } \\
\text { input and } \mathrm{CO}_{2} \text { emissions } \\
\text { as undesirable output }\end{array}$ & $\begin{array}{l}\text { DDF and SS-Malmquist } \\
\text { Luenberger productivity } \\
\text { index (combination of } \\
\text { sequential DEA and } \\
\text { super efficiency DEA) }\end{array}$ & $\begin{array}{l}\text { Growth of China driven } \\
\text { by large inputs and } \\
\text { environmental } \\
\text { deterioration and } \\
\text { overestimated if } \mathrm{CO}_{2} \\
\text { emission not considered. }\end{array}$ \\
\hline $\begin{array}{l}\text { Chen and } \\
\text { Golley [6] }\end{array}$ & Industry & $\begin{array}{l}\text { Estimate the changing } \\
\text { patterns of green TFP } \\
\text { of Chinese } \\
\text { industrial sectors }\end{array}$ & $\begin{array}{l}\text { Energy consumption as } \\
\text { input; } \mathrm{CO}_{2} \text { as } \\
\text { undesirable output }\end{array}$ & $\begin{array}{l}\text { DDF and ML } \\
\text { productivity index }\end{array}$ & $\begin{array}{l}\text { Chinese industry not yet } \\
\text { on path towards } \\
\text { sustainable, low-carbon } \\
\text { growth. }\end{array}$ \\
\hline Kumar [7] & country & $\begin{array}{l}\text { Examine conventional } \\
\text { and environmentally } \\
\text { sensitive TFP in } 41 \\
\text { developed and } \\
\text { developing nations }\end{array}$ & $\begin{array}{l}\text { Energy as input and } \mathrm{CO}_{2} \\
\text { emissions as } \\
\text { undesirable output }\end{array}$ & $\begin{array}{l}\text { Directional Distance } \\
\text { Function and } \\
\text { Malmquist-Luenberger } \\
\text { productivity index }\end{array}$ & $\begin{array}{l}\text { Environmentally } \\
\text { sensitive measure of } \\
\text { productivity higher with } \\
\text { countries with higher } \\
\text { GDP/capita; openness } \\
\text { of a country will increase } \\
\text { its TFP. }\end{array}$ \\
\hline Wang et al. [8] & $\begin{array}{l}\text { Regional } \\
\text { level }\end{array}$ & $\begin{array}{l}\text { Measure environmental } \\
\text { efficiency, TFP growth } \\
\text { and its components } \\
\text { in China }\end{array}$ & $\begin{array}{l}\text { Energy as input, } \mathrm{SO}_{2} \\
\text { and } \mathrm{COD} \text { as } \\
\text { undesirable outputs }\end{array}$ & $\begin{array}{l}\text { SBM-DDF and } \\
\text { Luenberger productivity } \\
\text { index }\end{array}$ & $\begin{array}{l}\text { Overuse of energy and } \\
\text { environmental pollution } \\
\text { are major causes of } \\
\text { environmental } \\
\text { inefficiency. }\end{array}$ \\
\hline Boyd et al. [9] & Firm level & $\begin{array}{l}\text { Plant level productivity, } \\
\text { efficiency and } \\
\text { environmental } \\
\text { performance of container } \\
\text { glass industry in the U.S. }\end{array}$ & $\mathrm{NO}_{\mathrm{x}}$ emissions & $\begin{array}{l}\text { DDF and } \\
\text { Malmquist Index }\end{array}$ & $\begin{array}{l}\text { Technological process } \\
\text { and efficiency can } \\
\text { improve productivity; } \\
\text { emissions control can } \\
\text { lower productivity. }\end{array}$ \\
\hline $\begin{array}{l}\text { Picazo-Tadeo } \\
\text { et al. [10] }\end{array}$ & Firm level & $\begin{array}{l}\text { Evaluate the } \\
\text { environmental } \\
\text { regulation effect on } \\
\text { Spanish firms' } \\
\text { performance }\end{array}$ & $\begin{array}{l}\text { Energy as input; Watery } \\
\text { mud and used oil as } \\
\text { undesirable outputs }\end{array}$ & $\begin{array}{l}\text { Directional technology } \\
\text { distance function }\end{array}$ & $\begin{array}{l}\text { Environmental rules } \\
\text { encourage firms to } \\
\text { increase desirable output } \\
\text { by behaving efficiently. }\end{array}$ \\
\hline
\end{tabular}


Table 1. Cont.

\begin{tabular}{|c|c|c|c|c|c|}
\hline Study & Scope & $\begin{array}{l}\text { Major Issues } \\
\text { Addressed }\end{array}$ & Inputs/Outputs & Methodology & Major Conclusions \\
\hline $\begin{array}{l}\text { Watanabe and } \\
\text { Tanaka [11] }\end{array}$ & $\begin{array}{l}\text { Provincial } \\
\text { level }\end{array}$ & $\begin{array}{l}\text { Traditional and green } \\
\text { efficiency measure of } \\
\text { Chinese industry at } \\
\text { provincial level }\end{array}$ & $\begin{array}{l}\text { Energy as input, } \mathrm{SO}_{2} \\
\text { and } \mathrm{COD} \text { as } \\
\text { undesirable outputs }\end{array}$ & $\begin{array}{l}\text { SBM-DDF and } \\
\text { Luenberger productivity } \\
\text { index }\end{array}$ & $\begin{array}{l}\text { Environmental pollution } \\
\text { and overuse of energy } \\
\text { are major causes of } \\
\text { environmental } \\
\text { inefficiency. }\end{array}$ \\
\hline Cao [12] & industry & $\begin{array}{l}\text { Recognize the } \\
\text { importance of efficiency } \\
\text { improvements in terms } \\
\text { of pollution abatement }\end{array}$ & $\begin{array}{l}\text { Energy as input and TSP, } \\
\mathrm{SO}_{2} \text { and } \mathrm{NO}_{\mathrm{X}} \text { as } \\
\text { undesirable outputs }\end{array}$ & $\begin{array}{l}\text { Solow Function and } \\
\text { Transformation Function }\end{array}$ & $\begin{array}{l}\text { Increasingly stringent } \\
\text { environmental } \\
\text { regulations will improve } \\
\text { environmental efficiency } \\
\text { in industrial sectors. }\end{array}$ \\
\hline $\begin{array}{c}\text { Zhou and Ang } \\
\text { [13] }\end{array}$ & $\begin{array}{l}21 \mathrm{OECD} \\
\text { countries }\end{array}$ & $\begin{array}{l}\text { Measure energy } \\
\text { efficiency performance }\end{array}$ & $\begin{array}{l}\text { Energy as input and } \mathrm{CO}_{2} \\
\text { emissions as } \\
\text { undesirable output }\end{array}$ & $\begin{array}{l}\text { Non-radial DEA model } \\
\text { and Slacks-based DEA } \\
\text { model }\end{array}$ & $\begin{array}{l}21 \text { OECD countries as a } \\
\text { whole experienced little } \\
\text { change in overall energy } \\
\text { efficiency. }\end{array}$ \\
\hline Chen [14] & $\begin{array}{l}\text { Provincial } \\
\text { level }\end{array}$ & $\begin{array}{l}\text { Construct an } \\
\text { endogenously produced } \\
\text { evaluation indicator and } \\
\text { analyze ecological } \\
\text { economic transition for } \\
31 \text { provinces in China in } \\
1981-2012\end{array}$ & $\begin{array}{l}\text { Energy and electricity } \\
\text { consumption as inputs } \\
\text { and } \mathrm{CO}_{2} \text {, waste water, } \\
\text { waste gas, } \mathrm{COD}, \mathrm{SO}_{2} \text { as } \\
\text { undesirable outputs }\end{array}$ & $\begin{array}{l}\text { SBM-DEA and } \\
\text { Luenberger productivity } \\
\text { index }\end{array}$ & $\begin{array}{l}\text { Ecological transition not } \\
\text { yet stable in China and } \\
\text { government should } \\
\text { implement more } \\
\text { appropriate } \\
\text { environmental } \\
\text { regulations to realize } \\
\text { long-run sustainable } \\
\text { development. }\end{array}$ \\
\hline Wang et al. [15] & $\begin{array}{l}\text { Provincial } \\
\text { level }\end{array}$ & $\begin{array}{l}\text { measure the energy and } \\
\text { environmental efficiency } \\
\text { of } 29 \text { regions of China } \\
\text { during 2000-2008 }\end{array}$ & $\begin{array}{l}\text { Energy as input and } \mathrm{CO}_{2} \\
\text { and } \mathrm{SO}_{2} \text { as } \\
\text { undesirable outputs }\end{array}$ & $\begin{array}{l}\text { Non-radial input } \\
\text { oriented DEA model }\end{array}$ & $\begin{array}{l}\text { Eastern China has a } \\
\text { more balanced } \\
\text { development with } \\
\text { highest energy and } \\
\text { environment efficiency. }\end{array}$ \\
\hline
\end{tabular}

In addition to green TFP of industries, substantial attention has also been given in the academic literature to the empirical relationship between economic growth and environmental quality-the so-called Environmental Kuznets Curve (EKC) theory. In the study of the environmental effects of the North American Free Trade Agreement (NAFTA), Grossman and Krueger [16] found evidence in support of the EKC theory-environmental quality begins to worsen as per capita income rises up until an income threshold and improves as per capita income rises beyond that turning point. Their research was among the first to challenge the view that economic growth must always be accompanied by environmental degradation. However, results from more recent works have been mixed for various nations, including China (see Table 2 for a sample of related studies with particular emphasis on China). In some cases, evidence in favor of EKC was found $[17,18]$. In other cases, no evidence was found in favor of the theory [19]. The mixed results represented in Table 2 may be due in part to the diversity of methods and data sets used. To determine appropriate government policy response to environmental degradation in China, it is useful that we thoroughly characterize the relationship between environmental quality and economic growth.

In this paper, we empirically test the evidence for the EKC theory with respect to China's industrial economy in order to inform appropriate environmental policy; this is the main focus of this study. However, since it is likely that the relationship between industrial output per capita and pollutant emissions varies markedly across sectors depending on their sustainability profiles, we first estimate a measure of long-term sustainable industrial economic growth by computing the green TFP for each industrial sector. Then we cluster all sectors into groups of varying sustainability profile. The EKC analysis in this paper is presented for each of three clusters of industrial sectors based on green TFP profile. We find that the green TFP analyses for the industrial sectors provide interesting insights in their own right and thus will be discussed separately in the results section. While the EKC phenomenon is typically analyzed on a national scale, the sectoral analyses presented in this paper still maintains the national perspective while shedding light on the role of technology in the relative contributions of different industrial sectors to total pollutant loads. The sectoral analysis also allows us to investigate how policy instruments can be customized for different sectors to improve the cost-effectiveness of pollutant reduction strategies. 
Table 2. Summary of scope, methodology and conclusions of related studies on EKC in China.

\begin{tabular}{|c|c|c|c|c|c|}
\hline Study & Scope/Period & Major Issues Addressed & Indicators & Methodology & Major Conclusions \\
\hline Song et al. [17] & $\begin{array}{l}\text { Provincial data } \\
\text { from } 1985 \text { to } 2005\end{array}$ & $\begin{array}{l}\text { Investigate relationship } \\
\text { between environmental } \\
\text { pollution and economic } \\
\text { growth in China }\end{array}$ & $\begin{array}{l}\text { Waste gas, waste } \\
\text { water and } \\
\text { solid wastes }\end{array}$ & $\begin{array}{l}\text { Panel } \\
\text { co-integration test } \\
\text { and dynamic OLS }\end{array}$ & $\begin{array}{l}\text { The environmental } \\
\text { pollutants exhibit } \\
\text { inverted U-shaped, } \\
\text { which satisfies } \\
\text { EKC theory. }\end{array}$ \\
\hline Du et al. [20] & $\begin{array}{l}\text { Provincial panel } \\
\text { data from China in } \\
1995 \text { to } 2009\end{array}$ & $\begin{array}{l}\text { Investigate driving force, } \\
\text { emission trends and reduction } \\
\text { potential of China's } \\
\mathrm{CO}_{2} \text { emission }\end{array}$ & $\mathrm{CO}_{2}$ emissions & $\begin{array}{l}\text { Both static and } \\
\text { dynamic panel } \\
\text { data models are } \\
\text { estimated }\end{array}$ & $\begin{array}{l}\text { Results do not strongly } \\
\text { support inverted } \\
\text { U-shaped relationship } \\
\text { between per capita } \\
\mathrm{CO}_{2} \text { emissions and } \\
\text { economic growth. }\end{array}$ \\
\hline Wang et al. [21] & $\begin{array}{l}28 \text { provinces in } \\
\text { China over period } \\
199502997\end{array}$ & $\begin{array}{c}\text { Examine causal relationships } \\
\text { between } \mathrm{CO}_{2} \text { emissions, } \\
\text { energy consumption and } \\
\text { economic growth }\end{array}$ & $\begin{array}{l}\mathrm{CO}_{2} \text { emissions, } \\
\text { energy consumption } \\
\text { and real GDP }\end{array}$ & $\begin{array}{l}\text { Panel } \\
\text { co-integration and } \\
\text { panel vector error } \\
\text { correction model }\end{array}$ & $\begin{array}{l}\text { There is a U-shaped } \\
\text { curve between } \\
\text { economic growth and } \\
\mathrm{CO}_{2} \text { emissions with a } \\
\text { turning point of } \\
3287 \text { RMB. }\end{array}$ \\
\hline $\begin{array}{l}\text { Jayanthakumaran } \\
\text { et al. [23] }\end{array}$ & $\begin{array}{l}\text { Data from China } \\
\text { and India from } \\
1971-2007\end{array}$ & $\begin{array}{l}\text { Test long-run and short-run } \\
\text { relationship between growth, } \\
\text { trade, energy use and } \mathrm{CO}_{2} \\
\text { emissions }\end{array}$ & $\begin{array}{l}\text { Per capita income, } \\
\text { per capita } \mathrm{CO}_{2} \\
\text { emissions, per capita } \\
\text { energy consumption } \\
\text { and trade intensity }\end{array}$ & ARDL method & $\begin{array}{l}\text { EKC theory exists in } \\
\text { both China and India. }\end{array}$ \\
\hline
\end{tabular}

Following previous work on this subject, we use the Slacks-Based Measure (SBM; Fukuyama and Weber [24]) Directional Distance Function (DDF; Chung et al. [25]) and the Global Malmquist-Luenberger (GML; Oh [26])) productivity index to measure the green TFP of China's industrial sector using data covering the 2001-2011 period. We further calculate the contribution of green TFP to rate of industrial economic growth as the primary measure of transition of industrial sectors to sustainable development. Finally, we empirically test the relationship between environmental pollution and China's industrial economic growth for each sector by using three different environmental pollution indicators: wastewater, $\mathrm{SO}_{2}$ and solid waste. Given the relevant data on industrial sector outputs and pollutant contributions, evidence in favor of or against the EKC theory would help inform appropriate policies to address the environmental footprint of China's industrial economy.

\section{Research Methods and Analytical Frameworks}

\subsection{Calculation of Green Total Factor Productivity}

The first step in our analysis is to calculate green TFP values for each industrial sector, in order to cluster all industries based on sustainability profile and perform separate EKC analyses for each cluster. As indicated above, numerous studies have attempted to estimate green TFP in order to better characterize the environmental footprint of industries. Green TFP is an indicator of sustainability of production processes since unlike a standard TFP measure, it accounts also for undesirable outputs such as environmental pollutants. High or increasing green TFP values are an indication that production technologies or systems are transitioning to a more sustainable mode. Chung et al. [25] estimated green TFP using a DDF approach, while Fukuyama and Weber [24] extended this by using a directional SBM to estimate technical inefficiency through a Data Envelopment Analysis (DEA) approach. In this paper, we follow Fukuyama and Weber [24] by using a directional SBM to estimate green TFP for China's industrial sector. We chose this method because it provides more flexibility to characterize green TFP values for all the industrial sectors. We begin by augmenting the production set to include both desirable and undesirable outputs. 
Consider every industrial sector in China as a separate Decision-Making Unit (DMU). We assume that each DMU uses $M$ inputs to produce $H$ desirable outputs, with the concomitant release of $J$ undesirable outputs. Let $x, y$ and $b$ represent the inputs, desirable outputs and undesirable outputs, respectively. Then the production technology can be expressed as:

$$
P(x)=\left\{(y, b): x \rightarrow(y, b), x \in R_{M^{\prime}}^{+}, y \in R_{H}^{+}, b \in R_{J}^{+}\right\}
$$

We assume that the technology set is convex and closed. Here, convexity implies that given any two points within the set, a convex combination of those points also lies within the set. We further assume, as in previous works, that the desirable outputs are null-joint with undesirable outputs: that is, a positive quantity of desirable outputs can be produced only if positive amounts of undesirable outputs are also generated [25-27]. We also assume that desirable outputs are freely disposable, that is: $(y, b) \in P(x)$ and $y^{\prime} \leq y$ imply $\left(y^{\prime}, b\right) \in P(x)$. Finally, we assume that undesirable outputs are weakly disposable and that inputs are strongly disposable. By weak disposability we mean that it is costly to reduce the amount of undesirable outputs generated, or specifically, $(y, b) \in P(x)$ and $0 \leq \theta \leq 1$ imply $(\theta y, \theta b) \in P(x)$. Furthermore, by strong disposability of inputs we mean that we can always produce the same level of output if we have the same or a greater amount of input than was used to generate that output level.

Chung et al. [25] introduced the DDF-an extension of Shephard's output distance function [28] - which allows one to increase desirable outputs while simultaneously decreasing undesirable outputs. Specifically,

$$
\vec{D}(x, y, b ; \vec{g})=\sup \{\tau:(y, b)+\tau \vec{g} \in P(x)\}
$$

where $\vec{g}=\left(\vec{g}_{x}, \vec{g}_{y}, \vec{g}_{b}\right)$ is the direction vector, which can be configured to result in the simultaneous increase in desirable outputs and decrease in undesirable outputs.

Using the DDF, the traditional Malmquist-Luenberger (ML) productivity indices are defined as geometric means of ratios of the above distance functions for two consecutive time periods [14]:

$$
M L^{t, t+1}=\left[\frac{\left\{1+\vec{D}^{t}\left(x^{t}, y^{t}, b^{t} ; y^{t}, b^{t}\right)\right\}\left\{1+\vec{D}^{t+1}\left(x^{t}, y^{t}, b^{t} ; y^{t}, b^{t}\right)\right\}}{\left\{1+\vec{D}^{t}\left(x^{t+1}, y^{t+1}, b^{t+1} ; y^{t+1}, b^{t+1}\right)\right\}\left\{1+\vec{D}^{t+1}\left(x^{t+1}, y^{t+1}, b^{t+1} ; y^{t+1}, b^{t+1}\right)\right\}}\right]^{\frac{1}{2}}
$$

However, as shown in various studies [29], the ML index is not circular, in that it is derived from two ratios with different base technologies. In fact, it is computed as a geometric mean of two ratios because each is based on a different base technology, making measures of technological progress less intuitive in the absence of a uniform reference technology. Besides the problem of the ML index not being circular, infeasible solutions may be encountered when linear programming procedures are applied to decompose the index. Consequently, Pastor and Lovell [29] proposed a new index based on a global benchmark technology, which is defined as the envelope of the technologies corresponding to all time periods represented in the data set. Specifically,

$$
\begin{aligned}
& P^{t}\left(x^{t}\right)=\left\{\left(y^{t}, b^{t}\right): x^{t} \rightarrow\left(y^{t}, b^{t}\right)\right\}, t=1, \ldots, T, \text { and } \\
& P^{G}(x)=P^{1}\left(x^{1}\right) \cup P^{2}\left(x^{2}\right) \cup \ldots \cup P^{T}\left(x^{T}\right)
\end{aligned}
$$

where, $P^{t}\left(x^{t}\right)$ is the production technology at time $t$ and $P^{G}(x)$ is the envelope of all the contemporaneous production technologies, that is, the global benchmark production technology set. 
Given the DDF defined above and the global technology set, the new index, the Global Malmquist Luenberger (GML) productivity index is circular and is free from the other problems inherent in the ML index. The GML index can readily be specified as:

$$
G M L^{t, t+1}=\frac{1+\vec{D}^{G}\left(x^{t}, y^{t}, b^{t} ; y^{t}, b^{t}\right)}{1+\vec{D}^{G}\left(x^{t+1}, y^{t+1}, b^{t+1} ; y^{t+1}, b^{t+1}\right)}
$$

where $t, t+1$ refer to time periods and $\vec{D}^{G}$ is the distance function defined on the global technology set. The GML index is not expressed as a geometric mean as this is no longer necessary. To enable a more intuitive expression of the GML index, it can be expressed as a product of two simple metrics. Essentially, by multiplying the top and bottom of (5) by the cross-period DDFs, the GML index above can be decomposed as:

$$
\begin{aligned}
G M L^{t, t+1} & =\frac{1+\vec{D}^{t}\left(x^{t}, y^{t}, b^{t}\right)}{1+\vec{D}^{t+1}\left(x^{t+1}, y^{t+1}, b^{t+1}\right)} \times \frac{\left(1+\vec{D}^{G}\left(x^{t}, y^{t}, b^{t}\right)\right) /\left(1+\vec{D}^{t}\left(x^{t}, y^{t}, b^{t}\right)\right)}{\left(1+\vec{D}^{G}\left(x^{t+1}, y^{t+1}, b^{t+1}\right)\right) /\left(1+\vec{D}^{t+1}\left(x^{t+1}, y^{t+1}, b^{t+1}\right)\right)} \\
& =\frac{T E^{t+1}}{T E^{t}} \times \frac{B P G_{t+1}^{t, t+1}}{B P G_{t}^{t+1}} \\
& =G M L E C^{t, t+1} \times G M L T C^{t, t+1} .
\end{aligned}
$$

where the additional arguments from the direction vector $\vec{g}$ - that is, $y^{t}, b^{t}, y^{t+1}$ and $b^{t+1}$-have, without loss of generality, been subsumed to simplify the expressions. In the above equation, $T E^{t}$ represents the technical efficiency of the period $t$ production process and $B P G_{t+1}^{t, t+1}$ is the best practice gap between the optimal global production technology frontier and the production technology frontier at period $t$ along the direction $\left(y^{t}, b^{t}\right)$. Thus $G M L T C^{t, t+1}$, the ratio of $B P G_{t+1}^{t, t+1}$ and $B P G_{t}^{t, t+1}$, is in essence the ratio of best practice gaps between two time periods $t$ and $t+1$, a measure of technical change. The change in technical efficiency is represented by GMLEC $C^{t, t+1}$ and represents the change in the distance from the optimal production frontier to the current technology between time periods $t$ and $t+1$. If $G M L E C^{t, t+1}>1$, it means the production process in period $t+1$ is closer to the optimal production frontier than in the previous period, implying a higher efficiency. If $G M L E C^{t, t+1}<1$, it means the production process in period $t+1$ is further from the optimal production frontier as compared to period $t$, implying a lower efficiency. Similarly, if $G M L T C^{t, t+1}>1$, the production technology of period $t+1$ is closer to the global production technology as compared to period $t$. Conversely, $G M L T C^{t, t+1}<1$ represents technological retrogression. On the other hand, $C^{t, t+1}=1$, implies there is no technical change between the two adjacent periods. Finally, $G M L^{t, t+1}>1$ indicates an increase in productivity and $G M L^{t, t+1}<1$ indicates a decrease in productivity.

Given a set of observations $n=1, \ldots N$, on the inputs and outputs, we can estimate the green TFP and draw inferences about EKC for China's industrial sector. In light of the data, the output set defined in (1) above is represented as:

$$
P(x)=\left\{\begin{array}{c}
(x, y, b): \sum_{n=1}^{N} z_{n} x_{m n} \leq x_{m}, m=1, \ldots, M ; \sum_{n=1}^{N} z_{n} y_{h n} \geq y_{h}, h=1, \ldots, H ; \\
\sum_{n=1}^{N} z_{n} b_{j n}=b_{j}, j=1, \ldots, J ; z_{n} \geq 0, n=1, \ldots, N \\
\sum_{n=1}^{N} z_{n}=1
\end{array}\right\}
$$

where $z_{n}, n=1, \ldots N$ are the activity intensity levels that reflect the combinations of inputs and outputs selected. Note that we allow for variable returns to scale by including the constraint $\sum_{n=1}^{N} z_{n}=1$.

Decomposition of the GML index is accomplished by DEA. Tone [30,31] proposed a non-radial, non-angular SBM for more accurate measurement of green TFP to address overcapacity, lack of 
desirable outputs and other issues in the actual production process. In a later study Fukuyama and Weber [24] combined the SBM with the DDF to obtain the directional SBM function:

$$
\begin{gathered}
\vec{S}_{v}^{t}\left(x_{i}^{t}, y_{i}^{t}, b_{i}^{t} ; g^{x}, g^{y}, g^{b}\right)=\frac{1}{3} \max \left(\frac{1}{M} \sum_{m=1}^{M} \frac{s_{m}^{x}}{g_{m}^{x}}+\frac{1}{H} \sum_{h=1}^{H} \frac{s_{h}^{y}}{g_{h}^{y}}+\frac{1}{J} \sum_{j=1}^{J} \frac{s_{j}^{b}}{g_{j}^{b}}\right) \\
\text { s.t. } \quad \sum_{n=1}^{N} x_{m n} \lambda_{n}+s_{m}^{x}=x_{i m^{t}}^{t} m=1, \ldots, M ; \\
\quad \sum_{n=1}^{N} y_{h n} \lambda_{n}-s_{h}^{y}=y_{i h^{t}}^{t} h=1, \ldots, H ; \\
\sum_{n=1}^{N} b_{j n} \lambda_{n}+s_{j}^{b}=b_{i j}^{t}, j=1, \ldots, J ; \\
\sum_{n=1}^{N} \lambda_{n}=1 ; \lambda_{n} \geq 0, n=1, \ldots, N ; \\
s_{m}^{x} \geq 0 \forall m, s_{h}^{y} \geq 0 \forall h, s_{j}^{b} \geq 0 \forall j .
\end{gathered}
$$

where $\vec{S}_{v}^{t}$ represents the DDF under the condition of variable return to scale. If the assumption that the sum of the weight variables equals 1 is removed, the above becomes the DDF under constant returns to scale. The vectors $\left(x_{t}^{i}, y_{t}^{i}, b_{t}^{i}\right)$ represent the vectors of inputs, desirable outputs and undesirable outputs of the $i$-th production decision-making unit at period $t$. Finally, $\left(g^{x}, g^{y}, g^{b}\right)$ is the direction vector, representing the reduced inputs, increased desirable outputs and reduced undesirable outputs, respectively and $\left(s_{m}^{x}, s_{q}^{y}, s_{j}^{b}\right)$ represents the slack variables, reflecting the degree of overcapacity of inputs, reduced desirable outputs as well as undesirable outputs. When the actual production of the decision-making unit is not slacked, the SBM directional distance function is equal to the traditional DDF. In the empirical analysis presented below, we used the Slacks-Based DDF.

\subsection{Dynamics of Production Mode of Industrial Sectors}

Implementation of the production technology in this study uses Solow's Cobb Douglas functional form [32] and including energy consumption as a third input due to the fact that the rapid economic growth in China is coupled with its tremendous demand for energy consumption [6,8,11,33,34]:

$$
Y_{i t}=A_{i t} K_{i t}^{\alpha} L_{i t}^{\beta} E_{i t}^{\gamma}
$$

where, $Y_{i t}, A_{i t}, K_{i t}, L_{i t}$ and $E_{i t}$ represent gross industrial output, green TFP (accounting for undesirable outputs), capital input, labor input and energy input, respectively. By taking the logarithms and time differentiating, the equation above can be transformed into:

$$
1=\frac{g_{A_{i t}}}{g Y_{i t}}+\frac{\alpha g_{K_{i t}}}{g Y_{i t}}+\frac{\beta g_{L_{i t}}}{g Y_{i t}}+\frac{\gamma g_{E_{i t}}}{g Y_{i t}}
$$

The right-hand side of the equation above represents the contribution of green TFP, capital investment, labor input and energy consumption respectively to the rate of total industrial economic growth. Let $A T Y_{i t}$ represent the contribution of green TFP to industrial economic growth in sector $i$ at time period $t$. Then we have:

$$
A T Y_{i t} \equiv \frac{g A_{i t}}{g Y_{i t}}=\frac{\frac{A_{i t}-A_{i t-1}}{A_{i t-}}}{\frac{Y_{i t}-1}{Y_{i t-1}}}=\left(1+\frac{\alpha g_{K_{i t}}}{g A_{i t}}+\frac{\beta g_{L_{i t}}}{g A_{i t}}+\frac{\gamma g_{E_{i t}}}{g_{A_{i t}}}\right)^{-1}
$$

Based on Equation (11), the magnitude of $A T Y_{i t}$ is markedly dependent on the relative contributions of green TFP and the other factors of production. Specifically, if 
$\operatorname{sgn}\left(g_{A_{i t}}\right)=\operatorname{sgn}\left(\alpha g_{K_{i t}}+\beta g_{L_{i t}}+\gamma g_{E_{i t}}\right)$, then $\left|g_{A_{i t}}\right| \geq\left|\alpha g_{K_{i t}}+\beta g_{L_{i t}}+\gamma g_{E_{i t}}\right| \Rightarrow 0.5 \leq A T Y_{i t}<1$ and $\left|g_{A_{i t}}\right|<\left|\alpha g_{K_{i t}}+\beta g_{L_{i t}}+\gamma g_{E_{i t}}\right| \Rightarrow 0<A T Y_{i t}<0.5$.

In the first case, the contribution of green TFP is greater in magnitude than (or at least as large as) the weighted average contribution of all other factors of production and we say that the industry's growth is green-intensive. In the second instance, the contribution of green TFP is less and we say that the industry's growth is not green-intensive, or simply hereafter, that growth is extensive. In the less relevant situation where $\operatorname{sgn}\left(g_{A_{i t}}\right) \neq \operatorname{sgn}\left(\alpha g_{K_{i t}}+\beta g_{L_{i t}}+\gamma g_{E_{i t}}\right), A T Y_{i t}<0$ or $A T Y_{i t}>1$ depending on the relative contributions of green TFP and the other factors of production.

\subsection{Clustering of Industries Based on Sustainability Profile}

In the empirical estimations presented below, the time series of $A T Y_{i t}$ values for each industrial sector was used to classify all sectors into groups reflective of their production mode. A hierarchical clustering procedure was performed using STATA Version 14 (STATA [35]) to group all industrial sectors into green-intensive (sectors with increasing ATY values), intermediate and extensive clusters (sectors with decreasing ATY values) representing the diverse modes of production. Based on the cluster analysis, 14 industries were assigned to the green-intensive group (the group with most promise for long-term economic and environmental sustainability), 7 to the intermediate group and 15 to the extensive group (the cluster with least promise for long-term sustainability). Summary characteristics of each group are presented later in Section 4.1. Details of clustering analysis results are available in Supplementary Data.

\subsection{The EKC Model on China's Industrial Economy}

Given the clusters of industrial sectors based on green TFP values, we can now perform the EKC analyses for each group of sectors. Empirical characterization of the EKC model for China's industrial sectors is performed using the double log model:

$$
\begin{aligned}
& \text { lnPollut }_{i t}=\alpha_{0}+\alpha_{1} \ln G D P_{i t}+\alpha_{2}\left(\ln G D P_{i t}\right)^{2}+\alpha_{3}\left(\ln G D P_{i t}\right)^{3} \\
& +\beta E_{n e r g} y_{i t}+\mu_{i}+\varepsilon_{i t}
\end{aligned}
$$

where, $i$ represents an individual industrial sector, $t$ represents time period, Pollut $t_{i t}$ is the per capita environmental pollution level of industry $i$ at time period $t$ and $G D P_{i t}$ represents the per capita industrial output of industry $i$ at time period $t$. Energy $y_{i t}$ represents the level of energy input use in industry $i$ at time period $t$ as a percentage of total energy input use across all industrial sectors and is used here as a control variable in the model. By including energy as an explanatory variable, the authors are aware of potential endogeneity problems that may limit the validity of the econometric estimations. However, this was not deemed to be a significant concern in this specific application. The term $\mu_{i}$ represents the unobserved cross-sectional differences among various industries and $\varepsilon_{i t}$ is the random error term. Use of a polynomial expression in lnGDP enables us to estimate different models for each sector and each pollutant, based on the significance of the coefficients of each term in the polynomial expression. Essentially, the above polynomial functional form allows us to estimate linear, quadratic and cubic functions depending on the significance of the coefficients. Accordingly, a separate model selection process was not used in these estimations.

\section{Data Sources and Variable Description}

Data for this study were obtained for the 2001-2011 period from China Statistical Yearbook, China Industrial Economics Statistical Yearbook, China Energy Statistical Yearbook and China Environmental Statistical Yearbook. In order to ensure consistency and completeness of the data, we removed "other mining industry," "handicrafts and other products" and "waste resources and waste materials processing industry" from the data set prior to estimation due to the significant 
amount of missing data associated with those sectors. Data on the remaining 36 industrial sectors were used to calculate the green TFP of China's industrial economy. For the input variables, we used energy consumption, average annual balance of fixed assets and average annual number of employees as the energy, capital and labor variables, respectively. For the desirable output variable, we used industrial GDP per capita. To estimate environmental pollution levels, we assembled data on industrial wastewater, waste gas, solid waste and industrial carbon dioxide and used the entropy method to construct a comprehensive environmental pollution index. We used this index to represent the undesirable output variable in the GTFP computations. Note that in the subsequent EKC analyses, we used a separate index for each pollutant as required in that case. All data used in the empirical estimations were national totals for each industrial sector.

Since carbon dioxide data is not directly available from existing statistics, we estimated industrial carbon emissions using the Intergovernmental Panel on Climate Change's Greenhouse Gas Inventory Guide on (IPCC [36]):

$$
C_{t}=\sum_{v=1}^{3} C_{v t}=\sum_{v=1}^{3} E_{v t} \times N C V_{v} \times C E F_{v} \times C O F_{v} \times 44 / 12
$$

where, $C_{t}$ represents the industrial carbon dioxide emissions, $E_{v t}$ represents the total consumption of industrial coal, industrial crude oil and industrial natural gas by sector, $N C V_{v}$ represents the average low calorific value of the three energy sources and $C E F_{v}$ represents the carbon emission coefficient. Refer to the previous studies [37,38], the carbon emission coefficients in tons of carbon equivalent (tce) are 2.64t $\mathrm{CO}_{2} /$ tce for coal, 2.08t $\mathrm{CO}_{2} /$ tce for crude oil, $1.63 \mathrm{t} \mathrm{CO}_{2} /$ tce for natural gas, respectively. Finally, $C O F_{v}$ represents the carbon oxidation factor, which is 0.99 for coal and 1.0 for both crude oil and natural gas. The molecular weights of carbon dioxide (44) and carbon (12) are applied here to convert to $\mathrm{CO}_{2}$ equivalence.

As stated above, a double log functional form was used in the empirical study of the EKC model for China's industrial sector. Since scholars find mixed conclusions between various environmental pollutants and economic growth $[21-23,39]$, the environmental pollution variables were specified as the logarithm of industrial wastewater discharge per capita, logarithm of industrial sulfur dioxide emissions per capita and logarithm of industrial solid waste emissions per capita, respectively. The logarithm of industrial GDP per capita was used as the economic growth variable. We also used the ratio of the energy consumption in the individual industrial sector to the total industrial energy consumption as the control variable. The Harris-Tzavalis unit-root test [40] was applied in STATA Version 14 [37] to test for stationarity of the time series. Testing a unit-root null hypothesis against an alternative hypothesis of stationary time series, the $p$-values for all tests were practically zero, indicating sufficient evidence against the null hypothesis. The Im-Pesaran-Shin test produced a similar conclusion. Thus, the results indicated that all the variables were stationary and they were consequently used without further adjustments for the estimations.

\section{Empirical Results and Analysis}

\subsection{Empirical Analysis of Green Total Factor Productivity and Green Transition in China's Industrial Economy}

As mentioned above, green TFP values were computed for all industrial sectors, primarily as a precursor to classifying the sectors into groups and performing the EKC analysis for each cluster of sectors. However, the green TFP results are interesting and relevant in their own right and are thus discussed in this section prior to presentation of the EKC results. We present the green TFP values for each sector in Table 3, along with their decomposition and other relevant data. 
Table 3. Empirical results of green TFP among China's industrial sectors.

\begin{tabular}{|c|c|c|c|c|c|}
\hline Industrial Sectors & Green TFP & $\begin{array}{l}\text { Efficiency } \\
\text { Change }\end{array}$ & $\begin{array}{l}\text { Technological } \\
\text { Progress }\end{array}$ & ATY & $\begin{array}{l}\text { Industrial GDP } \\
\text { Per Capita (RMB) }\end{array}$ \\
\hline Green-Intensive Group & $\begin{array}{c}5.30 \% \text { b } \\
(0.92)\end{array}$ & $\begin{array}{c}1.91 \% \\
(2.15)\end{array}$ & $\begin{array}{c}4.26 \% \\
(0.61)\end{array}$ & $\begin{array}{c}34.63 \% \text { b } \\
(0.68)\end{array}$ & $702^{b}(1.12)$ \\
\hline Extraction of Petroleum and Natural Gas & $12.14 \%$ & $3.70 \%$ & $6.83 \%$ & $49.11 \%$ & 260 \\
\hline $\begin{array}{l}\text { Processing of Food from } \\
\text { Agricultural Products }\end{array}$ & $2.48 \%$ & $0.98 \%$ & $1.54 \%$ & $16.13 \%$ & 950 \\
\hline Manufacture of Foods & $2.98 \%$ & $1.14 \%$ & $1.87 \%$ & $78.97 \%$ & 390 \\
\hline Manufacture of Beverages & $6.52 \%$ & $2.99 \%$ & $3.44 \%$ & $7.76 \%$ & 350 \\
\hline Manufacture of Tobacco & $6.81 \%$ & $0.00 \%$ & $6.81 \%$ & $74.39 \%$ & 250 \\
\hline Manufacture of Textile & $3.67 \%$ & $5.68 \%$ & $4.12 \%$ & $80.13 \%$ & 1120 \\
\hline $\begin{array}{l}\text { Manufacture of Articles for Culture, } \\
\text { Education and Sport Activities }\end{array}$ & $0.04 \%$ & $0.00 \%$ & $0.05 \%$ & $-13.27 \%$ & 130 \\
\hline Manufacture of Medicines & $1.89 \%$ & $0.19 \%$ & $1.74 \%$ & $13.94 \%$ & 480 \\
\hline Manufacture of Chemical Fibers & $4.08 \%$ & $0.15 \%$ & $3.96 \%$ & $62.20 \%$ & 210 \\
\hline Manufacture of Plastics & $2.09 \%$ & $-2.68 \%$ & $9.23 \%$ & $34.28 \%$ & 490 \\
\hline Manufacture of Metal Products & $2.76 \%$ & $0.19 \%$ & $2.84 \%$ & $96.72 \%$ & 670 \\
\hline $\begin{array}{l}\text { Manufacture of Communication } \\
\text { Equipment, Computers and other } \\
\text { Electronic Equipment }\end{array}$ & $5.43 \%$ & $0.00 \%$ & $5.43 \%$ & $92.77 \%$ & 3070 \\
\hline $\begin{array}{c}\text { Production and Supply of Electric Power } \\
\text { and Heat Power }\end{array}$ & $18.84 \%$ & $14.32 \%$ & $7.18 \%$ & $73.87 \%$ & 1420 \\
\hline Production and Supply of Water & $4.53 \%$ & $0.00 \%$ & $4.53 \%$ & $59.09 \%$ & 40 \\
\hline Intermediate Group & $\begin{array}{c}4.80 \% \text { b } \\
(0.89)\end{array}$ & $\begin{array}{c}3.23 \% \\
(1.45)\end{array}$ & $\begin{array}{c}3.36 \% \\
(1.20)\end{array}$ & $\begin{array}{c}21.61 \% \\
(1.10)\end{array}$ & $741^{b}(0.87)$ \\
\hline Mining and Processing of Nonmetal Ores & $1.27 \%$ & $9.70 \%$ & $-3.78 \%$ & $45.36 \%$ & 80 \\
\hline $\begin{array}{c}\text { Manufacture of Textile, Wearing Apparel, } \\
\text { Foot ware and Caps }\end{array}$ & $3.01 \%$ & $-0.89 \%$ & $8.84 \%$ & $42.58 \%$ & 510 \\
\hline Manufacture of Furniture & $0.93 \%$ & $0.00 \%$ & $0.93 \%$ & $-1.50 \%$ & 150 \\
\hline $\begin{array}{l}\text { Manufacture of Raw Chemical Materials } \\
\text { and Chemical Products }\end{array}$ & $4.15 \%$ & $1.08 \%$ & $3.10 \%$ & $19.83 \%$ & 1500 \\
\hline $\begin{array}{l}\text { Manufacture of Non-metallic } \\
\text { Mineral Products }\end{array}$ & $6.69 \%$ & $2.60 \%$ & $3.74 \%$ & $-13.27 \%$ & 1050 \\
\hline Smelting and Pressing of Ferrous Metals & $13.36 \%$ & $10.15 \%$ & $6.53 \%$ & $12.73 \%$ & 1610 \\
\hline $\begin{array}{c}\text { Manufacture of Measuring Instruments } \\
\text { and Machinery for Cultural Activity and } \\
\text { Office Work }\end{array}$ & $4.17 \%$ & $0.00 \%$ & $4.17 \%$ & $45.53 \%$ & 290 \\
\hline Extensive Group & $\begin{array}{l}-3.99 \% \text { b } \\
(-1.38)\end{array}$ & $\begin{array}{l}-6.23 \% b \\
(-0.78)\end{array}$ & $\begin{array}{l}-5.84 \% \text { b } \\
(-0.24)\end{array}$ & $\begin{array}{c}16.86 \% \\
(0.90)\end{array}$ & $586^{b}(1.00)$ \\
\hline Mining and Washing of Coal & $15.15 \%$ & $11.32 \%$ & $4.13 \%$ & $44.26 \%$ & 400 \\
\hline $\begin{array}{c}\text { Mining and Processing of Ferrous } \\
\text { Metal Ores }\end{array}$ & $-5.62 \%$ & $-5.37 \%$ & $3.64 \%$ & $35.04 \%$ & 100 \\
\hline $\begin{array}{c}\text { Mining and Processing of Non-Ferrous } \\
\text { Metal Ores }\end{array}$ & $3.30 \%$ & $13.08 \%$ & $0.28 \%$ & $36.82 \%$ & 80 \\
\hline $\begin{array}{c}\text { Manufacture of Leather, Fur, Feather and } \\
\text { Related Products }\end{array}$ & $7.27 \%$ & $6.13 \%$ & $4.02 \%$ & $-16.99 \%$ & 320 \\
\hline $\begin{array}{l}\text { Processing of Timber, Wood, Bamboo, } \\
\text { Rattan, Palm and Straw Products }\end{array}$ & $2.29 \%$ & $3.20 \%$ & $4.91 \%$ & $15.64 \%$ & 230 \\
\hline $\begin{array}{l}\text { Manufacture of Paper and } \\
\text { Paper Products }\end{array}$ & $16.51 \%$ & $8.91 \%$ & $2.99 \%$ & $11.40 \%$ & 410 \\
\hline $\begin{array}{l}\text { Printing, Reproduction of } \\
\text { Recording Media }\end{array}$ & $7.27 \%$ & $2.39 \%$ & $2.61 \%$ & $19.02 \%$ & 150 \\
\hline $\begin{array}{l}\text { Processing of Petroleum, Coking and } \\
\text { Processing of Nuclear Fuel }\end{array}$ & $12.15 \%$ & $8.66 \%$ & $5.65 \%$ & $28.13 \%$ & 660 \\
\hline Manufacture of Rubber & $1.75 \%$ & $-0.18 \%$ & $2.03 \%$ & $12.73 \%$ & 210 \\
\hline
\end{tabular}


Table 3. Cont.

\begin{tabular}{|c|c|c|c|c|c|}
\hline Industrial Sectors & Green TFP & $\begin{array}{l}\text { Efficiency } \\
\text { Change }\end{array}$ & $\begin{array}{l}\text { Technological } \\
\text { Progress }\end{array}$ & ATY & $\begin{array}{l}\text { Industrial GDP } \\
\text { Per Capita (RMB) }\end{array}$ \\
\hline $\begin{array}{l}\text { Smelting and Pressing of } \\
\text { Non-ferrous Metals }\end{array}$ & $4.57 \%$ & $1.81 \%$ & $2.70 \%$ & $0.94 \%$ & 660 \\
\hline $\begin{array}{l}\text { Manufacture of General } \\
\text { Purpose Machinery }\end{array}$ & $8.48 \%$ & $5.57 \%$ & $3.16 \%$ & $16.25 \%$ & 1210 \\
\hline $\begin{array}{l}\text { Manufacture of Special } \\
\text { Purpose Machinery }\end{array}$ & $3.82 \%$ & $0.73 \%$ & $3.40 \%$ & $7.55 \%$ & 740 \\
\hline Manufacture of Transport Equipment & $7.72 \%$ & $6.05 \%$ & $3.01 \%$ & $15.56 \%$ & 2080 \\
\hline $\begin{array}{l}\text { Manufacture of Electrical Machinery } \\
\text { and Equipment }\end{array}$ & $6.03 \%$ & $4.05 \%$ & $2.67 \%$ & $8.84 \%$ & 1480 \\
\hline Production and Supply of Gas & $5.93 \%$ & $0.00 \%$ & $5.93 \%$ & $17.71 \%$ & 60 \\
\hline Sector Average & $5.68 \%$ & $3.21 \%$ & $3.73 \%$ & $31.38 \%$ & 660 \\
\hline
\end{tabular}

${ }^{a}$ Green transition rate is the contribution of green TFP to the rate of industrial economic growth; ${ }^{b}$ The mean and coefficient of variation (in parenthesis) are offered for each subgroup in bold typeface; ${ }^{c}$ Some sectors are shown to have negative green contribution rate, which may be due to a reduction in green contribution, or possibly due to the decreased investment in capital, labor and energy as compared to the previous time period.

\subsubsection{Decomposition of Green Total Factor Productivity in China's Industrial Economy}

Results of the empirical estimations of the GML indices for the 36 industrial sectors are presented in Table 3. Column 1 of the table displays the industrial sector, columns 2, 3 and 4 are the green TFP, efficiency index and technical progress index, respectively. Recall that green TFP is the product of the efficiency index and the technical progress index. However, the numbers in the table represent averages across the 11-year time period of the data. Consequently, the data in column 2 cannot be reproduced as the product of the corresponding numbers in columns 3 and 4 . Column 5 shows the contribution of green TFP to the rate of total industrial economic growth. Finally, column 6 shows the industrial GDP per capita in RMB.

The results in the table are arranged in separate sections for each of the clusters of industrial, first for green-intensive sectors, followed by sectors in the intermediate group and the extensive group in that order. The last row of the table shows average values across all industrial sectors. The results indicate that, on the whole, China's industrial economy experienced a slight increase in green TFP, with an average annual value of about $5.68 \%$ per year (last row of Table 3 ). The corresponding average annual growth rates of technological progress and technical efficiency are $3.21 \%$ and $3.73 \%$, respectively (last row of Table 3), indicating that both sources of growth contributed significantly to the improvement in China's industrial green TFP. These results indicate that, in general, China's industrial sector moved slowly towards greener production systems with technological progress being a slightly more prominent driver (57\%) than efficiency gains (43\%). However, given the modest average annual growth rate of green TFP, the degree of green transition of China's industrial economy deserves further study.

The results indicate a positive growth rate of green TFP for all industrial sectors, except for the ferrous metal mining sector, which is estimated to have an average annual growth rate of $-5.62 \%$. A few sectors are associated with higher green TFP, such as mining and washing of coal, extraction of petroleum and natural gas, manufacturer of paper and paper products, processing of petroleum, coking and nuclear fuel, smelting and pressing of ferrous metals and production and supply of electric power and heat. A few other sectors have relatively smaller but positive green TFP growth rates, such as manufacture of furniture and manufacture of culture, education and sport activities with $0.93 \%$ and $0.04 \%$ respectively. Unlike some of the existing literature, we discovered in this study that the higher growth rate of green TFP is associated with traditional pollution-intensive sectors, where the green production efficiency tends to be low, while the lower growth rate of green TFP is associated more with light industrial sectors that have smaller environmental footprints. 
There is anecdotal evidence in support of these results. In recent years, China has faced enormous international and domestic environmental management pressure and frequent air pollution incidents further show the increasing constraints of resources and the environment on the sustainable development of China's industrial economy. Therefore, the Chinese government has accelerated the pace of industrial green transition, that is, transition to greener technologies and the heavy industrial sectors have become the preferred goal of reform due to their environmental pollution-intensive characteristics. Through the introduction of high-tech processes, policy changes, structural upgrades and other reforms, heavy industrial sectors, such as mining of coal and natural gas, have shown a high potential of improvement towards the production frontier. On the contrary, sectors like telecommunication equipment and computer, which are very close to the best production frontier, have a relatively limited space for improvement, thus being associated with a lower growth rate of green TFP.

\subsubsection{Empirical Analysis on Green Transition of China's Industrial Economy}

The results (Table 3) also show that the average annual contribution of green TFP to the rate of industrial economic growth in China from year 2001 to 2011 is 31.4\%, indicating that China's rapid industrial economic growth was largely relying on the massive investment of traditional resources with an extensive development mode. The contribution of green TFP to industrial economic growth varies quite markedly among sectors. Consequently, a hierarchical clustering analysis was performed to divide the 36 sectors into three major groups based on the dynamics of the contribution of green TFP, namely green-intensive group, intermediate group and extensive group.

The sectors clustered into the green-intensive group are high-tech industries, such as telecommunications equipment, computer and other electronic equipment manufactures and these sectors themselves have certain technological innovation advantages, producing high proportions of value-added products. Other sectors in the green-intensive group are clean sectors with relatively low energy consumption and environmental pollution, such as cultural, education and sport activities. The average contribution of green TFP to the rate of China's industrial economic growth in the green-intensive group is $53.9 \%$, indicating an environmentally friendly development mode in this group. Furthermore, it is worthy of note that the average value of green TFP itself in the green-intensive group is relatively high at $7.2 \%$. This implies that as the green transition process of China's industrial economy continues to accelerate, these green-intensive sectors will continue to play a key role through both technological progress and efficiency improvements to enhance the contribution of green TFP to China's industrial economic growth.

The extensive group mainly includes resource-intensive sectors associated with serious environmental pollution emissions. The average contribution of green TFP to the rate of industrial economic growth in this group is $19.6 \%$, indicating that the sectors in this group still rely heavily on the massive investment of traditional resources, such as capital, labor and energy, instead of green TFP. Manufacture of leather, fur and related sectors even has a negative green TFP growth rate of $-5.6 \%$. Therefore, this high energy consumption, high resource input and high pollution production mode has slowed down the green transition process of China's industrial economy.

Besides the green-intensive group and the extensive group, there are few sectors that were assigned to the intermediate cluster. This group consists primarily of traditional industrial sectors and the contribution of green TFP to industrial economic growth is $21.5 \%$. The value of green TFP among the sectors varies and the results show that it was as high as $45.5 \%$ in manufacture of measuring instruments and machinery for cultural activity and office work, while it was $-13.1 \%$ for manufacture of non-metallic mineral products. The range of green contribution rates among sectors has increased the uncertainty of green transition in this group.

Overall, China's industrial economy currently still maintains the extensive development mode, in which economic growth largely relies on massive investment of capital, labor, energy and other traditional elements and green TFP has not yet become the main force of economic growth. At present, 
as land and labor costs are rising sharply in China, coupled with the challenge of an aging population, if China's industrial economic growth is unable to transition from extensive to green-intensive development mode, the industrial sector would face an unsustainable future.

\subsection{Empirical Analysis of the EKC Model on China's Industrial Sector}

The green TFP values enabled us to cluster all industrial sectors into three groups for the subsequent EKC analyses. Thus, given the classification of industries presented in the foregoing section, we now present empirical evidence in relation to the EKC theory with respect to China's industrial economy. The results shown here differ depending on the pollutant of interest, so the discussions are organized in separate sections below for wastewater discharge, sulfur dioxide emissions and solid waste emissions. In each section, the Hausman test was performed to inform the choice between fixed and random effects models of pollutant levels as functions of industrial GDP per capita. The results are shown in Tables 4-7, where the numbers in parentheses are the t-statistic values. The form of the relationship between each pollutant and industrial GDP per capita is also indicated in the tables as U-shaped, inverted U-shaped, N-shaped, upward sloping, or downward sloping. The results are presented for each cluster of industrial sectors.

\subsubsection{Industrial Wastewater Discharge Per Capita As the Major Environmental Pollution Index}

Based on the Hausman test, the fixed effects model was selected for the regressions involving the green-intensive group, while the random effects model was chosen for the intermediate group and the extensive group (Table 4). The empirical results show that there is an inverted-U shaped relationship between wastewater discharge and industrial economic growth in the intermediate group and extensive group. In other words, there is evidence in support of EKC in the intermediate group and extensive group. On the other hand, there is a U-shaped relationship between the two in the green-intensive group.

Table 4. The EKC model where industrial wastewater discharge as the major environmental pollution index.

\begin{tabular}{cccc}
\hline \multirow{2}{*}{ Estimate Model } & Green-Intensive Group & Intermediate Group & Extensive Group \\
\cline { 2 - 4 } & Fixed Effect & Random Effect & Random Effect \\
\hline$\alpha_{0}$ & -0.21 & -4.48 & -3.06 \\
lnGDP & $(-0.55)$ & $(-3.94)^{* * *}$ & $(-7.01)^{* * *}$ \\
& 0.94 & -3.10 & -1.00 \\
$($ LnGDP) & $(2.93)^{* * *}$ & $(-2.94)^{* * *}$ & $(-4.39)^{* * *}$ \\
$($ LnGDP) & 0.19 & -0.99 & -0.28 \\
& $(2.17)^{* *}$ & $(-3.05)^{* * *}$ & $(-4.56)^{* * *}$ \\
Energy & 0.01 & -0.09 & -0.02 \\
F-statistics & $(-2.56)^{*}$ & $(-2.96)^{* * *}$ & $(-4.55)^{* * *}$ \\
Hausman-test & -0.56 & -0.05 & 0.26 \\
No. of sample & $(-1.27)$ & $(-0.19)$ & $(0.83)$ \\
Shape of curve & 6.18 & 2.94 & 5.50 \\
Turning point (RMB) & 25.28 & 12.83 & 22.53 \\
\hline
\end{tabular}

The estimated model did not produce any statistically significant relationship between sulfur dioxide emissions and GDP. Numbers in parentheses are the t-statistic values, and * indicates significant at $10 \%,{ }^{* *}$ indicates significant at $5 \%$, and ${ }^{* * *}$ indicates significant at $1 \%$. 
Taking the green-intensive group as an example, a U-shaped relationship was found, with a turning point at RMB300. Except for a few sectors (shown in Table 5), industrial GDP per capita of most industries in this group has reached or surpassed the turning point and this suggests that the trend of environmental quality will deteriorate along with industrial economic growth.

Table 5. The industries that have reached the turning point with industrial wastewater discharge as the major environmental pollution index.

\begin{tabular}{cl}
\hline Green-Intensive group & $\begin{array}{l}\text { Extraction of Petroleum and Natural Gas, Manufacture of Tobacco, Culture, } \\
\text { Education and Sport Activities, Production and Supply of Water }\end{array}$ \\
\hline Intermediate group & $\begin{array}{l}\text { Chemical Materials and Chemical Products, Manufacture of Non-metallic } \\
\text { Mineral Products, Smelting and Pressing of Ferrous Metals }\end{array}$ \\
\hline \multirow{2}{*}{ Extensive group } & $\begin{array}{l}\text { Manufacture of General Purpose Machinery, Manufacture of Transport } \\
\text { Equipment, Manufacture of Electrical Machinery and Equipment }\end{array}$ \\
\hline
\end{tabular}

For the intermediate group, the turning point is RMB1000. The inverted U shape implies that pollution levels would increase as per capita GDP increases until per capita income reaches RMB 1000. Beyond that point, environmental pollution would decrease as income per capita increases. Based on the scope of the sample, only a few sectors (listed in Table 3) have reached the turning point, where further economic growth would lead to reductions in the industrial wastewater emissions. The other industries in this group have not reached the turning point that triggers environmental quality improvement as GDP per capita rises. Therefore, blindly increasing the industrial economic growth will only accelerate the discharge of industrial wastewater and deterioration of environmental quality.

The turning point for the extensive group is RMB900 and currently there are only a few industries (listed in Table 5) that have reached that point where environmental quality will improve as economic growth continues. Thus, as is the case with the intermediate group, the inverted U shape implies that wastewater pollution will increase initially as GDP per capita rises till a threshold, beyond which point waste-water pollution loads will fall as per capita income increases.

In sum, concerning industrial wastewater discharge, the GDP per capita for most industries is well below the range where economic growth can improve environmental quality. Therefore, currently, industrial economic growth will only accelerate the deterioration of environmental quality.

\subsubsection{Industrial Sulfur Dioxide Emission Per Capita As the Major Environmental Pollution Index}

Results from the Hausman tests were used to select fixed effects models for the green-intensive group and extensive group, while a random effects model was chosen for the intermediate group (Table 6) in the case of industrial sulfur dioxide emissions. We find that there is no significant econometric relationship between industrial sulfur dioxide emissions and industrial GDP in the three groups. However, there is a marginally significant relationship between pollution levels and energy consumption in the green-intensive group. That is, continuous energy consumption will lead to an increase in industrial sulfur dioxide emissions, which is in line with actual data from production activities. To ensure a win-win situation between economic growth and environmental quality, clean and alternative energy sources may be needed, as well as enhanced production technology and efficiency so as to curb further deterioration of environmental quality. 
Table 6. The EKC model where industrial sulfur dioxide emissions as the major environmental pollution index.

\begin{tabular}{cccc}
\hline & Green-Intensive Group & Intermediate Group & Extensive Group \\
\cline { 2 - 4 } & Fixed Effect & Random Effect & Fixed Effect \\
\hline$\alpha_{0}$ & -21.18 & -20.37 & -20.66 \\
$\operatorname{lnGDP}$ & $(-7.50)^{* * *}$ & $(-2.33)^{* *}$ & $(-7.40)^{* * *}$ \\
& -1.27 & -10.49 & -1.15 \\
$($ LnGDP) & $(-0.54)$ & $(-1.24)$ & $(-0.48)$ \\
& 0.96 & -3.03 & 0.96 \\
$($ LnGDP) & $(1.51)$ & $(-1.18)$ & $(1.47)$ \\
& 0.06 & -0.31 & 0.08 \\
Energy & $(1.12)$ & $(-1.27)$ & $(1.42)$ \\
F-statistics & 5.66 & 2.14 & 3.43 \\
Hausman-test & $(1.74)^{*}$ & $(1.03)$ & $(1.04)$ \\
No. of sample & 87.32 & 41.24 & 80.40 \\
Shape of curve & 52.93 & 10.91 & 65.59 \\
Turning point(RMB) & 154 & 77 & 165 \\
\hline
\end{tabular}

${ }^{+}$The estimated model did not produce any statistically significant relationship between sulfur dioxide emissions and GDP. Numbers in parentheses are the t-statistic values, and * indicates significant at $10 \%$, ** indicates significant at $5 \%$, and $* * *$ indicates significant at $1 \%$.

\subsubsection{Industrial Solid Waste Emissions Per Capita As the Major Environmental Pollution Index}

The fixed effects model was selected for all three groups based on the Hausman tests (Table 7). The results presented in Table 7 indicate that there is no significant relationship between solid waste emissions per capita and industrial sector GDP per capita for the green-intensive and intermediate groups. However, an inverse (downward sloping) relationship exists for the extensive group suggesting a win-win situation between industrial economic growth and environmental pollution reduction when solid waste is the major pollutant.

Table 7. The EKC model where industrial solid waste emissions per capita as the major environmental pollution index.

\begin{tabular}{cccc}
\hline & Green-Intensive Group & Intermediate Group & Extensive Group \\
\cline { 2 - 4 } & Fixed Effect & Fixed Effect & Fixed Effect \\
\hline$\alpha_{0}$ & -14.69 & -13.73 & -15.79 \\
lnGDP & $(-11.64)^{* * *}$ & $(-6.83)^{* * *}$ & $(-15.39)^{* * *}$ \\
$($ LnGDP) & -0.96 & -0.36 & -2.49 \\
& $(-0.91)$ & $(-0.18)$ & $(-2.84)^{* * *}$ \\
$($ LnGDP) & -0.04 & 0.22 & -0.36 \\
& $(-0.13)$ & $(0.36)$ & $(-0.15)$ \\
Energy & -0.01 & 0.01 & -0.03 \\
F-statistics & $(-0.32)$ & $(0.23)$ & $(-1.32)$ \\
Hausman-test & 0.56 & -0.06 & 0.77 \\
No. of samples & $(0.39)$ & $(-0.12)$ & $(0.63)$ \\
Shape of curve & 14.75 & 18.15 & 30.14 \\
Turning point (RMB) & 34.13 & 22.65 & 115.01 \\
\hline The estimated model did not produce any statistically significant relationship between solid waste emissions and \\
GDP. Numbers in parentheses are the t-statistic values, and *indicates significant at 10\%, ${ }^{* *}$ indicates significant at \\
5\%, and *** indicates significant at 1\%.
\end{tabular}




\section{Summary and Conclusions}

China's industrial sectors have experienced tremendous growth over the past several decades but so have industrial pollutant emissions. This paper contributes to our understanding of the prospect for long-term sustainability of China's industrial sectors by determining whether there is sufficient evidence in favor of the EKC theory for each sector. We first calculate green TFP values for each sector and then cluster each sector into one of three groups depending on its sustainability profile. EKC analyses were then performed for each cluster of industrial sectors, since our a priori expectation was that the results would differ significantly across clusters. Our results show that on the whole, China's industrial economy experienced a slight increase in green TFP, with an average annual value of about $5.68 \%$ per year. The corresponding average annual growth rates of technological progress and technical efficiency are $3.21 \%$ and $3.73 \%$, respectively, indicating that China's industrial sector moved slowly towards greener production systems with technological progress being a slightly more prominent driver (57\%) than efficiency gains (43\%).

All 36 industrial sectors were grouped into three clusters reflecting their sustainability profile: 14 in the green-intensive group (sectors with most promise for long-term sustainability), 7 in the intermediate group and the remaining 15 in the extensive group (sectors with the least promise for long-term sustainability). EKC analyses were performed for each cluster and for each of three key pollutants: wastewater, $\mathrm{SO}_{2}$ and solid waste. The empirical results vary widely depending on the environmental pollutant of interest as well as industrial sectors. For wastewater, the results of the analyses indicate that the relationship between GDP per capita and environmental pollution could follow an inverted U-shape pattern (intermediate group and extensive group) or U shape pattern (green-intensive group). Consequently, evidence in favor of EKC was found only for the intermediate and extensive groups when wastewater is the pollutant of interest. However, based on the data available, the majority of the industrial sectors have not reached the threshold yet where accelerating economic growth will improve the environmental quality. For both sulfur dioxide and solid waste, the remaining two pollutants studied, no significant econometric relationship was found between GDP per capita and environmental pollution for any of the groups of industrial sectors. Thus, no evidence was found in support of the EKC theory with regards to these two pollutants.

Given the foregoing, it is apparent that environmental quality improvement is not an inevitable endogenous result of China's industrial growth. As China's economy continues to grow amidst concerns about environmental pollution, it is imperative that viable options be derived to ensure sustainable long-term economic growth without adverse impacts on the environment. The results indicate that a blanket policy of environmental regulations may not necessarily result in improved environmental outcomes as GDP per capita continues to rise. We find limited support for the EKC theory, except for the case of intermediate and extensive groups with regards to wastewater pollution and even in this case most industries are well below the turning point beyond which environmental pollution levels will fall as income per capita rises. The policy implication is that for wastewater pollution, regulatory intervention may be needed to curb environmental degradation until industrial output per capita reaches the above-referenced thresholds for industries in the intermediate and extensive groups. Beyond these thresholds, environmental regulation may be relaxed for these industries since further economic growth would be accompanied naturally by environmental quality improvement.

The policy prescription for other industries and for the other two pollutants is markedly different. Since we find no evidence in favor of the EKC theory in these instances, government regulatory instruments may need to be applied judiciously regardless of per capita output levels. With varied industries across a wide spectrum of pollution intensity, flexible regulatory instruments are called for. Furthermore, market-based incentive mechanisms may be preferred in many instances as a means to encouraging industrial innovation to speed up the green transition process of China's industrial economy. 
Acknowledgments: This work was partially funded by grants from Tarleton State University, primarily in support of a graduate thesis of the corresponding author. Views and opinions expressed in this article remain the sole responsibility of the authors and do not necessarily reflect the position of Tarleton State University or the Texas A\&M University System, or any other affiliations of the authors.

Author Contributions: Huijun Li and Edward Osei wrote the introduction, research methods and analytical frameworks, empirical results and analysis and conclusions. Jianhua Zhang and Mark Yu provided guidance and ideas and contributed to the revision of the manuscript. Huijun Li assembled the data and performed the empirical estimations.

Conflicts of Interest: The authors declare no conflict of interest.

\section{References}

1. PBL Netherlands Environmental Assessment Agency. Trends in Global $\mathrm{CO}_{2}$ Emissions-2016 Report; European Commission, Joint Research Centre: Brussels, Belgium, 2016.

2. Janssens-Manhout, G.; Grippa, M.; Guizzardi, D.; Muntean, M.; Schaaf, E.; Olivier, J.G.J.; Peters, J.A.H.W.; Schure, K.M. Fossil $\mathrm{CO}_{2}$ \& GHG Emissions of All World Countries; Joint Research Center: Brussels, Belgium, 2017.

3. Emrouznejad, A.; Yang, G. $\mathrm{CO}_{2}$ emissions reduction of Chinese light manufacturing industries: A novel RAM-based global Malmquist-Luenberger productivity index. Energy Policy 2016, 96, 397-410. [CrossRef]

4. Zhang, C.; Liu, H.; Bressers, H.T.A.; Buchanan, K.S. Productivity growth and environmental regulations-accounting for undesirable outputs: Analysis of China's thirty provincial regions using the Malmquist-Luenberger index. Ecol. Econ. 2011, 70, 2369-2379. [CrossRef]

5. Li, K.; Lin, B. Measuring green productivity growth of Chinese industrial sectors during 1998-2011. China Econ. Rev. 2015, 36, 279-295. [CrossRef]

6. Chen, S.; Golley, J. 'Green' productivity growth in China's industrial economy. Energy Econ. 2014, 44, 89-98. [CrossRef]

7. Kumar, S. Environmentally sensitive productivity growth: A global analysis using Malmquist-Luenberger index. Ecol. Econ. 2006, 56, 280-293. [CrossRef]

8. Wang, B.; Wu, Y.; Yan, P. Environmental efficiency and environmental total factor productivity growth in China's regional economies. Econ. Res. J. 2010, 5, 95-109.

9. Boyd, G.A.; Tolley, G.; Pang, J. Plant level productivity, efficiency and environmental performance of the container glass industry. Environ. Resour. Econ. 2002, 23, 29-43. [CrossRef]

10. Picazo-Tadeo, A.J.; Reig-Martinez, E.; Hernandez-Sancho, F. Directional distance functions and environmental regulation. Resour. Energy Econ. 2005, 27, 131-142. [CrossRef]

11. Watanabe, M.; Tanaka, K. Efficiency analysis of Chinese industry: A directional distance function approach. Energy Policy 2007, 35, 6323-6331. [CrossRef]

12. Cao, J. Measuring green productivity growth for China's manufacturing sectors: 1991-2000. Econ. J. 2008, 21, 425-451. [CrossRef]

13. Zhou, P.; Ang, B. Linear programming models for measuring economy-wide energy efficiency performance. Energy Policy 2008, 36, 2911-2916. [CrossRef]

14. Chen, S. The evaluation indicator of ecological development transition in China's regional economy. Ecol. Indic. 2015, 51, 42-52. [CrossRef]

15. Wang, K.; Yu, S.; Zhang, W. China's regional energy and environmental efficiency: A DEA window analysis based dynamic evaluation. Math. Comput. Model. 2018, 58, 1117-1127. [CrossRef]

16. Grossman, G.M.; Krueger, A.B. Environmental Impacts of a North American Free Trade Agreement; National Bureau of Economic Research Working papers; The National Bureau of Economic Research: Cambridge, MA, USA, 1991.

17. Song, T.; Zheng, T.; Tong, L. An empirical test of the environmental Kuznets curve in China: A panel co-integration approach. China Econ. Rev. 2008, 19, 381-392. [CrossRef]

18. Onafowora, O.; Owoye, O. Bounds testing approach to analysis of the environment Kuznets curve hypothesis. Energy Econ. 2014, 44, 47-62. [CrossRef]

19. He, J.; Richard, P. Environmental Kuznets Curve for $\mathrm{CO}_{2}$ in Canada. Ecol. Econ. 2010, 69, $1083-1093$. [CrossRef]

20. Du, L.; Wei, C.; Cai, S. Economic development and carbon dioxide emissions in China: Provincial panel data analysis. China Econ. Rev. 2012, 23, 371-384. [CrossRef] 
21. Wang, S.; Zhou, D.; Zhou, P.; Wang, Q. $\mathrm{CO}_{2}$ emissions, energy consumption and economic growth in China: A panel data analysis. Energy Policy 2011, 39, 4870-4875. [CrossRef]

22. Jalil, A.; Mahmud, S.F. Environmental Kuznets curve for $\mathrm{CO}_{2}$ emissions: A co-integration analysis for China. Energy Policy 2009, 37, 5167-5172. [CrossRef]

23. Jayanthakumaran, K.; Verma, R.; Liu, Y. $\mathrm{CO}_{2}$ emissions, energy consumption, trade and income: A comparative analysis of China and India. Energy Policy 2012, 42, 450-460. [CrossRef]

24. Fukuoka, H.; Weber, W. A directional Slacks-Based measure of technical efficiency. Soc.-Econ. Plan. Sci. 2009, 43, 274-287. [CrossRef]

25. Chung, Y.H.; Färe, R.; Grosskopf, S. Productivity and undesirable outputs: A directional distance function approach. J. Environ. Manag. 1997, 51, 229-240. [CrossRef]

26. Oh, D. A Global Malmquist-Luenberger productivity index. J. Product. Anal. 2010, 34, 183-197. [CrossRef]

27. Färe, R.; Grosskopf, S.; Pasurka, C.A. Pollution abatement activities and traditional productivity. Ecol. Econ. 2007, 62, 673-682. [CrossRef]

28. Shephard, R.W. Theory of Cost and Production Functions; Princeton University Press: Princeton, NJ, USA, 1970; ISBN 0691620806.

29. Pastor, J.T.; Lovell, C.A.K. A Global Malmquist productivity index. Econ. Lett. 2005, 88, 266-271. [CrossRef]

30. Tone, K. A Slacks-Based measure of efficiency in Data Envelopment Analysis. Eur. J. Oper. Res. 2001, 130, 498-509. [CrossRef]

31. Tone, K. A Slacks-Based measure of super-efficiency in Data Envelopment Analysis. Eur. J. Oper. Res. 2002, 143, 32-41. [CrossRef]

32. Solow, R. Technical change and the aggregate production function. Rev. Econ. Stat. 1957, 39, 312-320. [CrossRef]

33. Jeon, B.M.; Sickles, R.C. The role of environmental factors in growth accounting. J. Appl. Econ. 2004, 19, 567-591. [CrossRef]

34. Zheng, S.; Yi, H.; Li, H. The impacts of provincial energy and environmental policies on air pollution control in China. Renew. Sustain. Energy Rev. 2015, 49, 386-394. [CrossRef]

35. StataCorp. Stata Statistical Software: Release 14; StataCorp LP: College Station, TX, USA, 2015.

36. Intergovernmental Panel on Climate Change (IPCC). Tracking Greenhouse Gases: An Inventory Mannual. 2017. Available online: http://climate.emb.gov.ph/wp-content/uploads/2016/06/GHG-Manual.pdf (accessed on 24 December 2017).

37. Li, B.; Peng, X.; Ouyang, M. Environmental regulation, green total factor productivity and transformation of China's industrial development mode-Analysis based on data of China's 36 industries. China Ind. Econ. 2013, 4, 56-68.

38. Energy Foundation: Interim Measure for the Promotion and Administration of Engergy-Saving and Low-Carbon Technologies. Available online: http:/ / www.efchina.org/Reports-zh/reports-20140110-zh (accessed on 25 December 2017).

39. Jalil, A.; Feridun, M. The impact of growth, energy and financial development on the environment in China: A co-integration analysis. Energy Econ. 2011, 33, 284-291. [CrossRef]

40. Harris, R.D.F.; Tzavalis, E. Inference for unit roots in dynamic panels where the time dimension is fixed. J. Econom. 1999, 91, 201-226. [CrossRef]

(C) 2018 by the authors. Licensee MDPI, Basel, Switzerland. This article is an open access article distributed under the terms and conditions of the Creative Commons Attribution (CC BY) license (http://creativecommons.org/licenses/by/4.0/). 